\title{
Comparison of anti-HER2 antibody immobilization using three different techniques on aluminum-aluminum nitride-aluminum thin films produced by radiofrequency sputtering
}

\author{
This article was published in the following Dove Press journal: \\ Nanobiosensors in Disease Diagnosis \\ 20 August 2015 \\ Number of times this article has been viewed
}

\section{Julio Hernández \\ Mirna García \\ Dalia Gómez \\ Joaquín Oseguera}

Monterrey Institute of Technology and Higher Education, Campus State of Mexico, Atizapan of Zaragoza, State of Mexico, Mexico
Correspondence: Julio Hernández Instituto Tecnológico y de Estudios Superiores de Monterrey, Campus Estado de Mexico, Carretera Lago de Guadalupe Km.3.5 Atizapan de Zaragoza Col. Margarita Maza de Juarez, CP 52926, Mexico

$\mathrm{Tel}+52$ I55 54149909

Email azzaelhm@gmail.com

\begin{abstract}
Aluminum-aluminum nitride-aluminum thin films were deposited by radiofrequency reactive magnetron sputtering on silicon wafers (111). A comparison of three different methods of antibody immobilization relevant for surface modification in biosensor development was undertaken. Antibodies against human epidermal growth factor receptor 2 (HER2), a fundamental protein marker in breast cancer diagnostics, were used as a model in protein identification assays. The techniques evaluated were direct (random) immobilization, alginate (ionic) immobilization, and protein $\mathrm{G}$ (oriented) immobilization. Standardized detection capabilities were measured by enzyme-linked immunosorbent assay, and revealed substantial outcomes and differences for each technique. Immobilization using protein $\mathrm{G}$ was more efficient. Although immobilization using alginate had lower detection sensibility, it may be compared in sensitivity in some cases and is a more affordable technique.
\end{abstract}

Keywords: human epidermal growth factor receptor 2, antibody immobilization, biosensor, sputtering

\section{Introduction}

An estimated 1.38 million women worldwide were diagnosed with breast cancer in 2008, making this disease the second most diagnosed malignancy after lung cancer. ${ }^{1}$ Human epidermal growth factor receptor 2 (HER2) can be used as a model to study breast cancer because it is an important cancer-associated protein and thus can be used as a biomarker. ${ }^{2}$ Biomarkers for cancer include all measurable or observable factors that can be associated with either normal or disease-related states in cancer metabolism. ${ }^{3}$ Overexpression of HER 2 occurs in 25\%-30\% of human breast cancers and is associated with a particularly aggressive form of the disease. ${ }^{4}$ The surfaceimmobilized antibodies used in the present study target the HER2 protein, also known as ErbB2, Neu, or CD340.5,6

The HER2/neu gene is a proto-oncogene located on chromosome $17 \mathrm{q} 21 .{ }^{7}$ From this gene, a transmembrane glycoprotein of 1,255 amino acids with a molecular weight of $185 \mathrm{kDa}$ and tyrosine kinase activity is produced. ${ }^{8} \mathrm{HER} 2$ is part of a family of four cell surface receptors (HER 1-4) that share important homology with the epidermal growth factor receptor. When expressed in cells at normal levels, HER2 regulates cell growth, differentiation, and survival. ${ }^{9}$ However, overexpression and/or amplification of HER2 in certain cell types results in generation of numerous HER2 heterodimers that later become responsible for uncontrolled cell division, leading to cancer. ${ }^{9}$ 
It has been found that some cancer cells, particularly in the breast, have extra copies of the HER2 gene; as a consequence, there is increased production, signaling, activation, and overexpression of the HER2 protein. Therefore, it is important to be able to detect changes in HER 2 concentration in the human body. ${ }^{3,10}$ Biosensors, specifically immunosensors, are among the most important diagnostic tools available because of the specificity of the antibodies that they use as probes and because of the simplicity and rapidity with which such assays can deliver reliable results. ${ }^{11}$ For the purposes of the research reported here, a biosensor is defined as a compact analytical device incorporating a biological or biologically derived sensing element either integrated within or intimately associated with a physicochemical transducer. ${ }^{12,13}$

Immunosensors are important diagnostic tools, mainly because of their high specificity and the small volume of sample required to perform the assay. Sensitivity is a key factor in the performance of a sensor, ${ }^{14}$ and antibody immobilization is an essential step during development of the immunosensor in order to obtain this high sensitivity. The main objective of this study was to obtain a well oriented layer of antibodies, minimizing the number of steric hindrances and uncovered surfaces, in order to increase the capacity of the antibody-modified surface to bind with an important cancer biomarker. An adequate antibody immobilization technique makes it possible to obtain higher biosensor performance, and it has been demonstrated that the immobilization layers have an important role with regard to sensitivity, ${ }^{15,16}$ although the immobilized particles as well as the base surface may be able to modify the performance of the biosensor. ${ }^{17-19}$ In this study, radiofrequency magnetron reactive sputtering was used to deposit thin film sandwiches of aluminum-aluminum nitride-aluminum (Al-AlN-Al). This surface configuration, as reported by Wingqvist, ${ }^{20}$ can be used to produce a piezoimmunosensor. After deposition of the thin film, three different methods of antibody immobilization were evaluated in order to obtain the conditions that achieve the best sensitivity on the surface, ie, direct immobilization on the surface, immobilization using protein $\mathrm{G}$, and immobilization using sodium alginate. The latter method is based on adsorption of antibodies due to the polyelectrolyte nature of alginate. ${ }^{21}$

Although a considerable number of antibody immobilization methods have been described, the method that uses protein $\mathrm{G}$ is among the most widely recommended. Protein $\mathrm{G}$ binds to the Fc region of the antibody (immunoglobulin G), promoting correct orientation of the antibody's paratope, so an increase in biosensor efficiency and sensitivity is expected. ${ }^{11,22}$
The importance of this study lies in the fact that it compares different antibody immobilization methods as well as their performance on surfaces with different structures. The main objective was to determine which combination of antibody immobilization methods and surface grain size has the best sensitivity. These results are relevant for diagnosis when an immunosensor is required for early disease screening and could lead to development of a low-cost production tool using available technology in developing countries. Among women aged 50 and older, studies have demonstrated a $20-40 \%$ reduction in breast cancer mortality for women screened by mammography and clinical breast examination. ${ }^{23-25}$

\section{Materials and methods Thin film deposition}

Al-AlN-Al thin films were deposited using a novel radiofrequency magnetron sputtering system built at Tec de Monterrey, Nuevo León, Mexico. A schematic representation of the process has been published by Acosta et al. ${ }^{26}$ The chamber is equipped with a water-cooled magnetron that holds a target disk 2.5 inches in diameter. The aluminum target was $99.999 \%$ pure. The substrates were silicon wafers that were cleaned by washing in water, then soaking in ethanol (96\%), followed by rinsing in acetone (99.99\%) in an ultrasonic bath for 10 minutes and drying in a hot air flow. To begin the deposition process, the substrate was placed in front of the target at a $6 \mathrm{~cm}$ distance. A process involving two different working pressures was used to make the sandwich thin film depositions. Briefly, the method consisted of depositing an $\mathrm{Al}$ thin film at $2.66 \mathrm{~Pa}$ and then decreasing the working pressure to $0.266 \mathrm{~Pa}$ to deposit the AlN thin film. A lower pressure is used in order to enhance the surface diffusion of AlN and obtain films with good crystalline quality. ${ }^{20} \mathrm{AlN}$ was formed by interaction of the $\mathrm{Al}$ target with nitrogen flowing into the reaction chamber. After completing the deposition of AlN, the nitrogen flow was stopped, the chamber conditions were returned to work at a higher pressure (2.66 Pa), and a third layer consisting of $\mathrm{Al}$ was deposited. The radiofrequency power was varied to obtain different grain sizes in the substrate. The operational conditions are listed in Table 1. The final product of radiofrequency sputtering was a structure that could become a competitive and low-cost alternative to quartz crystal microbalance in disease diagnostics. ${ }^{20}$

Figure 1 shows scanning electron microscopic images of the three different surface groups that we prepared. The process parameters were chosen in order to produce cubic AlN on the surfaces, as shown in the X-ray diffraction pattern in Figure 2. 
Table I Operational conditions for aluminum-aluminum nitridealuminum thin film deposition

\begin{tabular}{lll}
\hline Condition & Al deposition & AIN deposition \\
\hline Deposition pressure $(\mathrm{Pa})$ & 2.66 & 0.266 \\
Argon flux $(\mathrm{scc})$ & 30 & 15 \\
Nitrogen flux $(\mathrm{scc})$ & 0 & 15 \\
Radiofrequency power $(\mathrm{W})$ & $50,100,150$ & 150 \\
Distance $(\mathrm{cm})$ & 6 & 6 \\
\hline
\end{tabular}

Abbreviations: Al, aluminum; AIN, aluminum nitride; scc, standard cubic centimeter per minute.

The average grain size of each surface was customized by modifying the deposition parameters. The first group had an average columnar grain size of $584 \mathrm{~nm}$ (ie, large grain size, "L" group), the second group had an average columnar grain size of $328 \mathrm{~nm}$ (mid grain size, "M" group), and the third group had an average columnar grain size of $201 \mathrm{~nm}$ (small grain size, "S" group). The sizes were measured by random sampling and no specific distribution was obtained. Following deposition of the thin film, the slides were cut into rectangular pieces $(0.5 \mathrm{~cm}$ base $\times 1 \mathrm{~cm}$ height $)$. These fragments were biofunctionalized with anti-HER 2 antibody and a comparison of antigen detection sensitivity was performed.

\section{Cleaning of the substrate surface}

Prior to any process involving use of organic compounds on the Al surface, the substrates were cleaned to remove any contaminants that may have been deposited during handling or storage. Cleaning was done by immersing the $0.5 \mathrm{~cm}^{2}$ substrates in piranha solution $\left(1: 330 \% \mathrm{H}_{2} \mathrm{O}_{2}\right.$ and concentrated $\mathrm{H}_{2} \mathrm{SO}_{4}$ ), rinsing with deionized water, and drying in a hot air flow. This process was carried using a laminar flow cabinet under sterile conditions.

\section{Direct immobilization of anti-HER2}

First, $0.5 \mathrm{~cm}^{2}$ surfaces of each grain size were incubated with $60 \mu \mathrm{L}$ of anti-HER2 antibody $(10 \mu \mathrm{g} / \mathrm{mL}$ in phosphatebuffered saline [pH 7.4] and 50\% v/v glycerol) for 2 hours at $4^{\circ} \mathrm{C}$. For this, the antibodies are attached randomly to the surface with no specific paratope orientation. After incubation, the slides were washed three times with $400 \mu \mathrm{L}$ of Tris-buffered saline and Tween 20 (TBST) per wash to remove the nonbound antibodies. The surface was blocked by incubation with $60 \mu \mathrm{L}$ of $10 \mathrm{mg} / \mathrm{mL}$ bovine serum albumin for 30 minutes at room temperature to prevent any cross-reactions that could result in false-positive detection of antigen. Next, a wash in $400 \mu \mathrm{L}$ of TBST was performed to eliminate the excess bovine serum albumin, followed by three washes in $400 \mu \mathrm{L}$ of phosphatebuffered saline ( $\mathrm{pH}$ 7.4) to remove any pollutants.

\section{Immobilization of anti-HER2 using sodium alginate}

The substrates were incubated with $60 \mu \mathrm{L}$ of a sodium alginate solution $(0.5 \%$ in phosphate-buffered saline, $\mathrm{pH} 5.0)$ for 12 hours at room temperature in the manner described by Wang et al. ${ }^{21}$ The substrates were next washed three times with $400 \mu \mathrm{L}$ of distilled water to remove any unbound alginate content, and then air-dried. Antibody immobilization was started by incubating the alginate-fixed surface with $60 \mu \mathrm{L}$ of the antibody ( $10 \mu \mathrm{g} / \mathrm{mL}$ in phosphate-buffered saline [pH 5.5]) for 2 hours at $4^{\circ} \mathrm{C}$. The slides were then washed three times using $400 \mu \mathrm{L}$ of phosphate-buffered saline ( $\mathrm{pH} 7.0$ ), followed by a final wash in $400 \mu \mathrm{L}$ of distilled water to remove any unbound antibodies on the surface. This was followed by air-drying. The surface was blocked by incubating the substrates with $60 \mu \mathrm{L}$ of bovine serum albumin $10 \mathrm{mg} / \mathrm{mL}$ which bound in the alginate regions where no antibody had been immobilized and thus prevented any false-positive results. Finally, the surfaces were washed three times with $400 \mu \mathrm{L}$ of phosphate-buffered saline ( $\mathrm{pH} 7.0)$ to remove any residual bovine serum albumin or pollutants, and finally air-dried.

\section{Immobilization of anti-HER2 using protein $\mathrm{G}$}

Two substrate groups were used to study protein $G$ immobilization. Each substrate group was incubated with
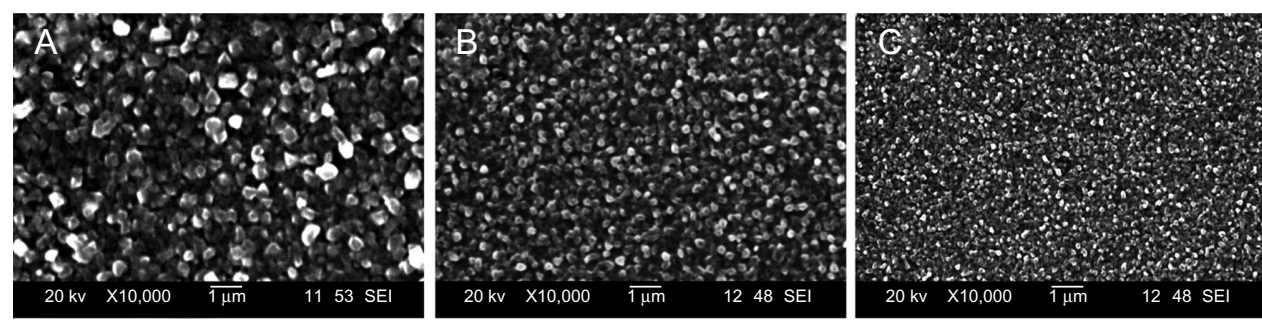

Figure I Scanning electron microscopic images of the surfaces in the three different groups in the study

Notes: (A) $584 \mathrm{~nm},(\mathbf{B}) 328 \mathrm{~nm}$, and (C) $201 \mathrm{~nm}$. Groups of slides with these surfaces were biofunctionalized with anti-HER2 antibodies using protein G, sodium alginate, or direct adsorption. 


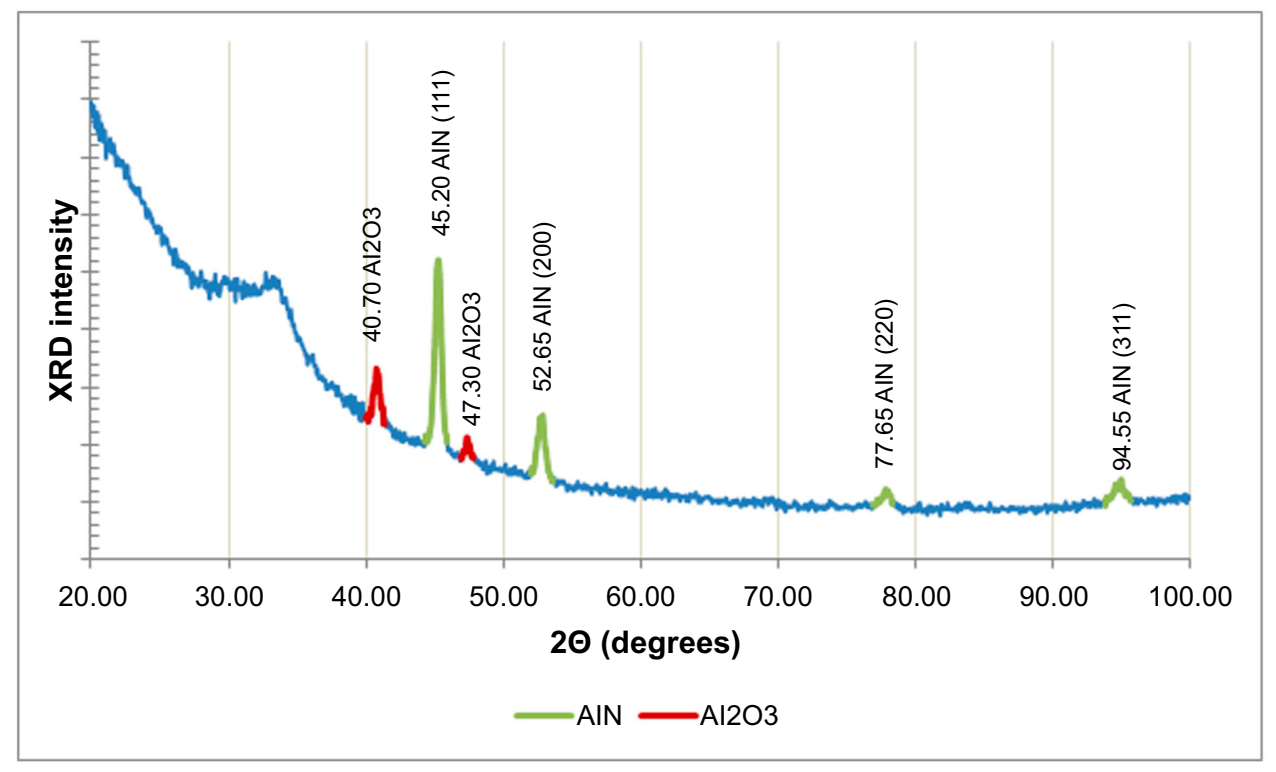

Figure 2 X-ray diffraction pattern of an aluminum-aluminum nitride-aluminum thin film layer on a silicon wafer. Cubic AIN (I I I) emission. Abbreviations: AIN, aluminum nitride; XRD, X-ray diffraction.

$60 \mu \mathrm{L}$ of protein $\mathrm{G}(1 \mu \mathrm{g} / \mathrm{mL}$ in phosphate-buffered saline [pH 7.4]) for either 2 or 12 hours at $4^{\circ} \mathrm{C}^{22}$ Guo et al used only a 2-hour incubation of protein $\mathrm{G}$ on commercially available aldehyde-derivatized slides, whereas Al surfaces were used in the present study. After incubation with protein $\mathrm{G}$, the slides were washed three times with $400 \mu \mathrm{L}$ of TBST. Next, $60 \mu \mathrm{L}$ of $10 \mathrm{mg} / \mathrm{mL}$ bovine serum albumin was added for 30 minutes at room temperature to block nonspecific surface binding sites. The surfaces were then washed with $400 \mu \mathrm{L}$ of TBST and rinsed three times with $400 \mu \mathrm{L}$ of phosphate-buffered saline to remove the remaining bovine serum albumin. The surfaces were next incubated with $60 \mu \mathrm{L}$ of anti-HER 2 for 2 hours at $4{ }^{\circ} \mathrm{C}$, followed by rinsing three times with $400 \mu \mathrm{L}$ of TBST. Subsequently, a second block with $60 \mu \mathrm{L}$ of $10 \mathrm{mg} / \mathrm{mL}$ bovine serum albumin was done by incubation for 30 minutes at room temperature. The substrates were then washed with $400 \mu \mathrm{L}$ of TBST, followed by three washes with $400 \mu \mathrm{L}$ of phosphate-buffered saline ( $\mathrm{pH}$ 7.4).

\section{Control group}

A control group for each surface size and immobilization technique was included, in which all procedures were performed as for the corresponding group, except that no primary antibody to be immobilized was added, with phosphate-buffered saline used instead. The control group therefore had no immobilized anti-HER2 antibody, and was used to eliminate background noise when reading in the spectrophotometer and to be able to discard falsepositive results.

\section{Standard HER2 curve}

An enzyme-linked immunosorbent assay (ELISA) was performed according to the instructions manual of the ELISA kit for human HER2 (\#KHO0701; Invitrogen, Carlsbad, CA, USA). Briefly, HuHER2 protein (antigen) was reconstituted (to $25 \mathrm{ng} / \mathrm{mL}$ ) by adding $1 \mathrm{~mL}$ of the standard diluent buffer to the vial where it was swirled gently, in order to make a homogeneous solution. A series of 2:1 dilutions was done to obtain HER2 samples at concentrations of 25, 12.5, 6.25, $3.13,1.56,0.78$, and $0.39 \mathrm{ng} / \mathrm{mL}$. This process was necessary in order to have a reliable reference source to be able to compare and identify HER 2 detection using a consistent commercially available tool.

The ELISA assay to make a HER2 standard curve was developed in an eight-well strip, following the manufacturer's instructions. Seven wells were designated for the standards $(0,0.39,0.78,1.56,3.13,6.25$, and $12.5 \mathrm{ng} / \mathrm{mL}$ of HER 2$)$; a final well was used as the chromogen blank, and contained only $100 \mu \mathrm{L}$ of the stabilized chromogen and $100 \mu \mathrm{L}$ of the stop solution. This assay was performed under sterile conditions.

\section{Evaluation of antigen detection}

The antigen (HER2) was incubated on the biofunctionalized surfaces. All slides, including the controls, were tested with $60 \mu \mathrm{L}$ of HER $2(1.56 \mathrm{ng} / \mathrm{mL})$ after 2 hours of incubation at room temperature. This process is decisive in the forthcoming results, as in this step the surface-fixated antibody specifically recognizes the antigen that is in the medium binding it. 
After incubation, the liquid remaining on the surface was discarded and the wells were washed four times in $400 \mu \mathrm{L}$ of wash buffer (10 mM phosphate buffer [pH 7.4], $150 \mathrm{mM} \mathrm{NaCl}, 0.05 \%$ Tween 20 ) to remove unbound protein. Subsequently, $60 \mu \mathrm{L}$ of HuHER 2 detection antibody was added to each surface, and incubated for one hour at room temperature. In this step, the second anti-HER2 antibody binds to the antigen, forming a sandwich antibody-antigenantibody. Afterwards, the liquid from the wells/surfaces was discarded and four washes were done using $400 \mu \mathrm{L}$ of wash buffer to eliminate unbound antibodies.

Next, $60 \mu \mathrm{L}$ of anti-rabbit immunoglobulin G horseradish peroxidase-conjugated antibodies was added to each surface, and incubated for 30 minutes at room temperature. This step involves high specificity, because the immunoglobulin $\mathrm{G}$ is a third antibody that binds to the antibody used in the previous step. It contains a horseradish peroxidase marker that is useful for revealing the antibody binding interaction. The excess liquid was then aspirated and discarded, and the wells were washed four times using $400 \mu \mathrm{L}$ of wash buffer.

Finally, $100 \mu \mathrm{L}$ of the stabilized chromogen was added to each well and surface. Upon contact with horseradish peroxidase, this chromogen triggers a chromatic reaction whereby the solution turns a blue color. The slides were incubated for 30 minutes at room temperature in the dark, and then $100 \mu \mathrm{L}$ of the stop solution was added to each well and surface. The colorimetric reaction stops at this point and the liquid becomes yellow. There is a direct relationship between the intensity of the color of the reaction and the amount of HER2 protein detected. Next, the absorbance for each assay was read using a spectrophotometer at $450 \mathrm{~nm}$.

\section{Results and discussion}

The deposited thin film surfaces are shown in Figure 1. The average grain size varied significantly between the groups, with the $\mathrm{L}$ group having an average grain size of $584 \pm 90.74 \mathrm{~nm}$, the $M$ group having an average grain size of $328 \pm 27.52 \mathrm{~nm}$, and the $S$ group having an average grain size of $201 \pm 20.25 \mathrm{~nm}$. Not only did the microstructure change, but so did the macrostructure. The first group (L) appeared opaque to the naked eye, while group $\mathrm{S}$ appeared shiny and group $\mathrm{M}$ had an appearance that was mid-way between those of the $\mathrm{L}$ and $\mathrm{S}$ groups. Another interesting feature was the change in behavior of the surfaces with regard to the ease of becoming wet. The L group easily adsorbed the solutions, and was difficult to keep dry, whereas the $\mathrm{S}$ group had difficulty adsorbing the solutions and was easy to wash and keep dry. This characteristic may be due to the roughness of the surface, ie, the group with the smallest grain size had a smooth surface and the one with the larger grain size is rough with larger spaces between the grains which can harbor micro basins of the solutions that are poured.

A model X Pert PRO MRD diffractometer (PANalytical, Oulu, Finland) and an X-ray tube with $\mathrm{Co}_{\alpha}(\lambda=1.79 \AA)$ radiation was used for further characterization of the thin film. A PIXcel $\left(2.5^{\circ}\right)$ area detector was used to obtain optical diffraction patterns of high quality. Measurements were made with symmetrical geometry $(\Theta-2 \Theta)$ by scanning from 20 to 100 degrees, with a step size of 0.05 and a time per step of 100 seconds. Figure 2 shows a $2 \Theta \mathrm{X}$-ray diffraction pattern for an Al-AlN-Al thin film deposited on silicon. The diffractogram shows the expected AlN patterns, along with the usual halo corresponding to an amorphous layer, plus the silicon substrate $\left(33.1^{\circ}\right)$. Various studies of AlN deposition on silicon substrates have been done before ${ }^{27-30}$ and obtained highly oriented AlN. Garcia-Mendez et a ${ }^{31}$ obtained polycrystalline growth on their deposits using glass as the substrate, as we obtained in these assays on silicon. This may be caused by the presence of oxygen. The presence of oxidized products in large amounts has been reported previously during growth of AlN films by sputtering. ${ }^{26}$ Oxygen appears to induce a degree of amorphous growth on the film and a distortion of the lattice parameters, ${ }^{31}$ inducing defects in the growth of AlN layers and having as a consequence, the amorphization of AlN films.

In healthy subjects, HER2 levels range from $2 \mathrm{ng} / \mathrm{mL}$ to 15 $\mathrm{ng} / \mathrm{mL},{ }^{32}$ so we selected a HER 2 concentration of $1.56 \mathrm{ng} / \mathrm{mL}$ to test the biofunctionalized surfaces. This concentration is ideal because it is below the expected lower normal value. Any concentration lower than this is not considered clinically relevant, so the minimum required sensing capability for our target biosensor was determined to be $2 \mathrm{ng} / \mathrm{mL}$. The presence of cancer tends to increase the amount of protein present. An advanced disease state in a patient produces concentrations of HER2 higher than $15 \mathrm{ng} / \mathrm{mL}$, reaching up to $75 \mathrm{ng} / \mathrm{mL}$. ${ }^{33}$

The surfaces were tested using $60 \mu \mathrm{L}$ of a single concentration of HER2 $(1.56 \mathrm{ng} / \mathrm{mL})$ as described earlier. The absorbance was then read and evaluated using the standard curve to determine a "standard concentration", so that we could compare the sensitivity of the different techniques. Figure 3 shows the HER 2 concentration read according to the technique used to immobilize the antibody, regardless of grain size. It should be noted that the concentration of HER 2 used did not vary, and the only relevant variable was the technique used to immobilize the antibody. It is possible to appreciate different behaviors on the concentration detection, when 


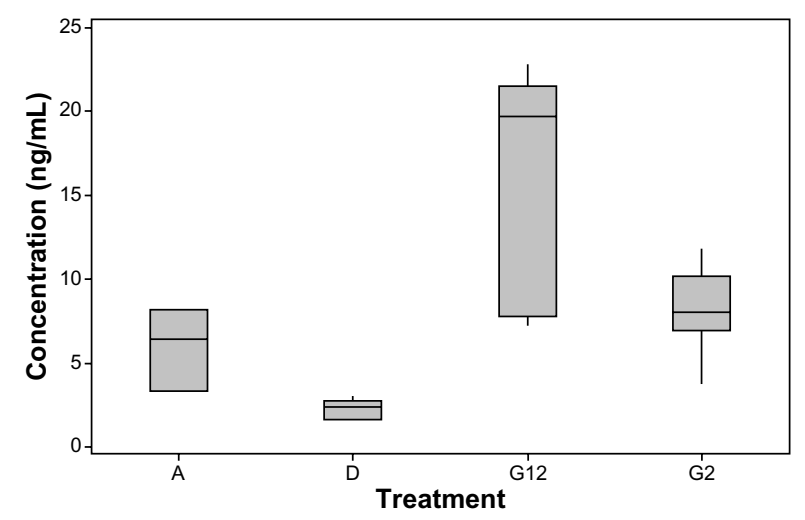

Figure 3 Box plot of concentration of HER2 detected on the surfaces of aluminumaluminum nitride-aluminum thin films, by different immobilization protocols, regardless of grain size.

Note: (A) Sodium alginate, (D) direct immobilization, (G I 2) 12 hours incubating protein G, and (G2) 2 hours incubating protein $G$.

interpolating in our standardized curve. Then, after making the statistical analysis, an important difference between treatments was found $(P<0.001)$.

The samples were read and interpolated on the standard curve. The best result was achieved using protein $G$ that had been incubated for 12 hours, with an average interpolated concentration detection limit of $16.44 \mathrm{ng} / \mathrm{mL}$, which falls outside the range on the standard curve, so a dilution of 1:1 had to be used to read the values accurately. Protein $\mathrm{G}$ incubated for 2 hours had an average concentration of $8.19 \mathrm{ng} / \mathrm{mL}$, the sodium alginate surfaces had an average concentration of $6.05 \mathrm{ng} / \mathrm{mL}$, and direct immobilization had the worst results, as expected, with an average concentration of $2.25 \mathrm{ng} / \mathrm{mL}$. As predicted, protein $\mathrm{G}$ showed better results than random immobilization, because protein $\mathrm{G}$ helps to orient the antibody's paratope and exposes it to the solution where the antigen is present. Guo et al appeared to find no difference in antigen detection whether they incubated their surfaces for 12 or 2 hours. ${ }^{22}$ One of the main differences lies in the surface used; Guo et al used an aldehyde-derivatized slide that could fix protein $\mathrm{G}$ more rapidly. In this study there was a variation in the results obtained on slides incubated with protein $\mathrm{G}$ for 12 or 2 hours, perhaps as a result of the more stable and uniform layer created by allowing the $\mathrm{G}$ protein to accumulate in the complex spaces present on the surface. Good results were expected for sodium alginate, but these were not as high as those obtained for the assay with protein G. It was found that sodium alginate was 2.6 times more effective for antigen detection than direct immobilization. This is a technique that does not specifically orient the antibodies, but rather works as a "glue", ${ }^{21}$ holding the antibodies on the surface and preventing detachment. This is useful because it gives stability to the sensing by keeping the same amount of antibodies on the surface, thereby lowering any possible variation between assays. Using alginate as an immobilizing layer may have the concern of having its natural negative charge not only binding the primary antibody, but also binding other kind of molecules such as antigen or secondary antibodies as well, which could lead to false-positive results. This possibility was prevented by blocking the layer with bovine serum albumin after immobilization of the primary antibody; further, every tested surface group included a control, which was used as a zero concentration target when reading in the spectrophotometer, thus eliminating both background noise and the possibility of false-positive results.

Table 2 shows the average concentration read in each group and a normalized reading, allowing a comparison of the techniques. For example, the alginate technique detected 2.689 more HER2 when compared with direct immobilization. The best result was obtained using protein $\mathrm{G}$, which was 7.302 times more sensitive than direct immobilization and 2.716 times more sensitive than sodium alginate immobilization.

The detected concentrations of HER2 were analyzed according to treatment used and average grain size. The results are presented in a box plot in Figure 4. In general, better HER2 detection was obtained as the grain size increased, with the exception of protein $\mathrm{G}$ incubated for 2 hours. Better HER2 detection appeared to be achieved using a medium grain size. In general, it is possible to achieve a higher detection rate as the grain size increases; this could be because the roughness increases the surface area and as a consequence a higher amount of antibodies can be attached.

The results for the slides that were incubated for 2 hours with protein $G$ may reflect the stability of the protein $G$ layer when comparing to the ones that were incubated 12 hours. It might require more time for the protein to attach steadily to the choppy microstructure of the surface with the biggest

Table 2 Average detected HER2 concentration per group

\begin{tabular}{lcll}
\hline & $\begin{array}{l}\text { Average } \pm \text { SD } \\
\text { concentration }\end{array}$ & $\begin{array}{l}\text { Normalized } \\
\text { with direct } \\
\text { immobilization }\end{array}$ & $\begin{array}{l}\text { Normalized } \\
\text { with alginate }\end{array}$ \\
\hline Alginate & $6.054 \pm 2.1$ & 2.689 & $\mathrm{I}$ \\
Direct & $2.25 \mathrm{I} \pm 0.5$ & 1.000 & $0.37 \mathrm{I}$ \\
$\mathrm{GI} 2 \mathrm{~h}$ & $16.443 \pm 6.7$ & 7.302 & 2.716 \\
$\mathrm{G} 2 \mathrm{~h}$ & $8.197 \pm 2.4$ & 3.640 & 1.353 \\
\hline
\end{tabular}

Note: The above values are standardized readings.

Abbreviations: SD, standard deviation; GI2h, 12 hours incubating protein G; G2h, 2 hours incubating protein G. 


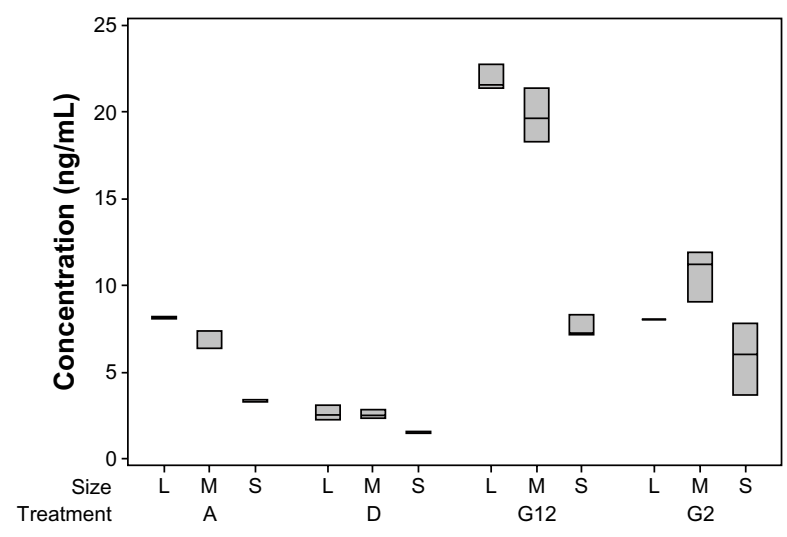

Figure 4 Box plot of the concentration of HER2 detected on the surfaces of aluminum-aluminum nitride-aluminum thin films, by different immobilization protocols, depending on the grain size of the surface.

Note: (A) Sodium alginate, (D) direct immobilization, (GI2) 12 hours incubating protein $G$, and (G2) 2 hours incubating protein $G$.

Abbreviations: L, large; $M$, medium; S, small; A, alginate immobilization; D, direct immobilization; GI2, protein G 12 hours; G2, protein G 2 hours.

grain size as it is more uneven than the surface with smaller grain size.

An interesting feature in our study was the direct immobilization technique. When a small grain size was used, the average absorbance corresponded to $1.58 \mathrm{ng} / \mathrm{mL}$ of HER2 when read and compared with the standard curve done using the commercially available kit. It should be noted that the solution was $1.56 \mathrm{ng} / \mathrm{mL}$, so a very similar result was obtained when comparing the surfaces developed against a commercially available tool.

The best result was obtained when protein $\mathrm{G}$ was immobilized for 12 hours over a large grain size (ie, the L group). This method was 13.8 times more sensitive than direct immobilization on a small grain size surface (ie, the $\mathrm{S}$ group). Finally, a further remarkable result was obtained when comparing the sodium alginate technique with the method involving incubation of protein $\mathrm{G}$ for 2 hours on a surface with a large grain size; both of them were analogous and about five times more sensitive than direct immobilization.

\section{Conclusion}

Al-AlN-Al thin films were biofunctionalized to be able to detect HER2 protein using an anti-HER2 antibody. Three different methods for antibody immobilization were used on surfaces with three different grain sizes. The best combination for sensitivity was achieved in the surface group where the protein $\mathrm{G}$ was incubated during 12 hours, on a surface with an average grain size of $584 \mathrm{~nm}$.

The 12-hour incubated sodium alginate layer yielded a similar result as a 2-hour incubated layer of protein $G$ regarding to sensitivity. This could be useful with regard to mass production of a biosensor, given that the cost of sodium alginate is much lower than that of protein G. Further analysis is required in order to compare these techniques, using covalent bonding for protein $\mathrm{G}$ and higher concentrations of alginate.

It is evident that there were different responses with regard to protein detection when the grain size and technique used were varied. Using an antibody-orienting coating, the sensitivity was increased by up to seven-fold when compared to an antibody immobilization method that causes random orientation. When both, not only the technique but the surface as well were modified, a surface as much as 21 times more sensitive was obtained, comparing with a random oriented antibody layer.

The sensitivity and stability of a biosensor are critical elements for evaluation. Factors other than technique or immobilization layer components, such as surface structure and characteristics, may modify these two crucial elements of biosensing. Consequently, it is possible to improve biosensing capabilities by using different antibody immobilization techniques and by modifying the surface itself.

The use of an alginate immobilization layer proved to be a feasible option instead of a protein $G$ immobilization layer, under specific circumstances both layers shown similar results to help to detect HER2. Additionally, alginatebiofunctionalized layers were able to detect clinically relevant concentrations of HER 2 protein, which makes these an ideal component when building biosensors, because alginate is a cheap and easily sourced component, making it a good alternative in developing economies.

\section{Acknowledgments}

The authors thank the Consejo Nacional de Ciencia y Tecnología for financially supporting this research and the biotechnology department of ITESM-CEM (Instituto Tecnologico y de Estudios Superiores de Monterrey. [Monterrey Institute of Technology and Higher Education]) for collaboration and use of its facilities.

\section{Disclosure}

The authors report no competing interests in this work.

\section{References}

1. Cancer Research UK. Cancer Stats. World Health Organization; 2011. Available from: http://publications.cancerresearchuk.org/downloads/ Product/cs_pdf_worldwide_2011.pdf. Accessed August 8, 2015.

2. Geyer CE, Forster J, Lindquist D, et al. Lapatinib plus capecitabine for HER2-positive advanced breast cancer. N Engl J Med. 2006;355(26): 2733-2743. 
3. Rusling JF, Kumar CV, Gutkind JS, Patel V. Measurement of biomarker proteins for point-of-care early detection and monitoring of cancer. Analyst. 2010;135(10):2496-2511.

4. Cobleigh MA, Vogel CL, Tripathy D, et al. Multinational study of the efficacy and safety of humanized anti-HER 2 monoclonal antibody in women who have HER2-overexpressing metastatic breast cancer that has progressed after chemotherapy for metastatic disease. J Clin Oncol. 1999;17(9):2639-2648.

5. Ueda Y, Wang S, Dumont N, Yi JY, Koh Y, Arteaga CL. Overexpression of HER2 (erbB2) in human breast epithelial cells unmasks transforming growth factor beta-induced cell motility. J Biol Chem. 2004;279(23): 24505-24513.

6. Qiao EQ, Ji M, Wu J, etal. Joint detection of multiple immunohistochemical indices and clinical significance in breast cancer. Mol Clin Oncol. 2013;1(4):703-710.

7. Marchiò C, Natrajan R, Shiu KK, et al. The genomic profile of HER2-amplified breast cancers: the influence of ER status. $J$ Pathol. 2008;216(4):399-407.

8. Peles E, Levy RB, Or E, Ullrich A, Yarden Y. Oncogenic forms of the neu/HER2 tyrosine kinase are permanently coupled to phospholipase C gamma. EMBO J. 1991;10(8):2077-2086.

9. Davoli A, Hocevar BA, Brown TL. Progression and treatment of HER2positive breast cancer. Cancer Chemother Pharmacol. 2010;65(4): 611-623.

10. Wolff AC, Hammond ME, Schwartz JN, et al. American Society of Clinical Oncology/College of American Pathologists guideline recommendations for human epidermal growth factor receptor 2 testing in breast cancer. Arch Pathol Lab Med. 2007;131(1):18-43.

11. Kausaite-Minkstimiene A, Ramanaviciene A, Kirlyte J, Ramanavicius A. Comparative study of random and oriented antibody immobilization techniques on the binding capacity of immunosensor. Anal Chem. 2010;82(15):6401-6408.

12. Dahlin AB. Size matters: problems and advantages associated with highly miniaturized sensors. Sensors. 2012;12(3):3018-3036.

13. Torsi L. Special issue on organic electronic bio-devices. Biosensors. 2013;3(1):116-119.

14. Wang Q, Zhang D, Yang H, et al. Sensitivity of a label-free guidedmode resonant optical biosensor with different modes. Sensors. 2012;12(7):9791-9799.

15. Blum L. Special issue immunosensors. Sensors. 2010;10. Available from http://www.mdpi.com/journal/sensors/special_issues/immunosensors. Accessed March 6, 2015.

16. Makaraviciute A, Ramanaviciene A. Site-directed antibody immobilization techniques for immunosensors. Biosens Bioelectron. 2013;50: $460-471$.

17. Mani V, Chikkaveeraiah BV, Patel V, Gutkind JS, Rusling JF. Ultrasensitive immunosensor for cancer biomarker proteins using gold nanoparticle film electrodes and multienzyme-particle amplification. ACS Nano. 2009;3(3):585-594.

18. Lee W, Oh BK, Lee WH, Choi JW. Immobilization of antibody fragment for immunosensor application based on surface plasmon resonance. Colloids Surf B Biointerfaces. 2005;40(3-4):143-148.
19. Bjurstrom J, Wingqvist G, Katardjiev I. Synthesis of textured thin piezoelectric AlN films with a nonzero $\mathrm{C}$-axis mean tilt for the fabrication of shear mode resonators. IEEE Trans Ultrason Ferroelectr Freq Control. 2006;53(11):2095-2100.

20. Wingqvist G. AlN-based sputter-deposited shear mode thin film bulk acoustic resonator (FBAR) for biosensor applications - a review. Surface and Coatings Technology. 2010;205(5):1279-1286.

21. Wang H, Li D, Wu Z, Shen G, Yu R. A reusable piezo-immunosensor with amplified sensitivity for ceruloplasmin based on plasmapolymerized film. Talanta. 2004;62(1):199-206.

22. Guo SL, Chen PC, Chen MS, et al. A fast universal immobilization of immunoglobulin $\mathrm{G}$ at 4 degrees $\mathrm{C}$ for the development of array-based immunoassays. PLoS One. 2012;7(12):e51370.

23. Michaelson JS, Halpern E, Kopans DB. Breast cancer: computer simulation method for estimating optimal intervals for screening. Radiology. 1999;212(2):551-560.

24. Streckfus C, Bigler L. The use of soluble, salivary c-erbB-2 for the detection and post-operative follow-up of breast cancer in women: the results of a five-year translational research study. Adv Dent Res. 2005;18(1):17-24.

25. Streckfus C, Bigler L, Dellinger T, Pfeifer M, Rose A, Thigpen JT. CA 15-3 and c-erbB-2 presence in the saliva of women. Clin Oral Investig. 1999;3(3):138-143.

26. Acosta J, Rojo A, Salas O, Oseguera J. Process monitoring during AlN deposition by reactive magnetron sputtering. Surface and Coatings Technology. 2007;201(18):7992-7999.

27. Meng WJ, Heremans J, Cheng YT. Epitaxial growth of aluminum nitride on Si(111) by reactive sputtering. Appl Phys Lett. 1991;59(17): 2097-2099.

28. Huang J, Wang L, Shen Q, Lin C, Östling M. Structural and electrical characterization of AIN thin films obtained by nitridation of Al/Si substrate. Journal of Electronic Materials. 1999;28(3): 225-227.

29. Saravanan S, Keim EG, Krijnen GJM, Elwenspoek MC. Growth and surface characterization of piezoelectric AlN thin films on silicon (100) and (110) substrates. In: Cullis AG, Hutchison JL, editors. Microscopy of Semiconducting Materials. Volume 107. Oxford, UK: Springer; 2005.

30. Assouar MB, El Hakiki M, Elmazria O, Alnot P, Tiusan C. Synthesis and microstructural characterisation of reactive RF magnetron sputtering AlN films for surface acoustic wave filters. Diam Relat Mater. 2004;13(4-8):1111-1115.

31. García-Méndez M, Morales-Rodríguez S, Eliézer Ramírez L, PérezTijerina E. Deposition of AIN and oxidized AIN thin-films by reactive sputtering: correlation between film growth and deposition parameters. Surface Review and Letters. 2008:453-458.

32. Gohring JT, Dale PS, Fan X. Detection of HER2 breast cancer biomarker using the opto-fluidic ring resonator biosensor. Sens Actuators B Chem. 2010;146(1):226-230.

33. Capobianco JA, Shih WY, Yuan Q-A, Adams GP, Shih W-H. Label-free, all-electrical, in situ human epidermal growth receptor 2 detection. Rev Sci Instrum. 2008;79(7):076101.
Nanobiosensors in Disease Diagnosis

\section{Publish your work in this journal}

Nanobiosensors in Disease Diagnosis is an international, peer-reviewed, open access journal publishing original research, reports, reviews and commentaries including but not confined to: Diagnosis of diseases including cancer, cardiovascular, infectious diseases; Molecular modeling in diagnosis; Enzyme and membrane technologies; and quantum
Dovepress

dot fluorescence technologies for monitoring toxins and pathogens. The manuscript management system is completely online and includes a very quick and fair peer-review system, which is all easy to use. Visit http://www.dovepress.com/testimonials.php to read real quotes from published authors. 